\title{
Reproductive biology of a highly endemic species: Cipocereus laniflorus N.P. Taylor \& Zappi (Cactaceae)
}

\author{
Juliana Ordones Rego ${ }^{1}$, Edivani Villaron Franceschinelli², and Daniela Cristina Zappi ${ }^{3}$
}

Recebido em 16/06/2010. Aceito em 13/02/2012

\begin{abstract}
RESUMO
(Biologia reprodutiva de uma espécie altamente endêmica: Cipocereus laniflorus Taylor \& Zappi (Cactaceae)). Cipocereus laniflorus N.P. Taylor \& Zappi é uma espécie endêmica da Serra do Caraça, Minas Gerais, Brasil. A fim de se propor estratégias de conservação para esta espécie, estudos sobre sua biologia reprodutiva foram realizados, incluindo fenologia reprodutiva, biologia floral, visitantes florais e o sistema reprodutivo. O período de floração e frutificação ocorre de maio a outubro. Poucas flores abrem-se por planta a cada noite, podendo produzir até $0.4 \mathrm{ml}$ de néctar, poré $30 \%$ destas não apresentam néctar. Cipocereus laniflorus provavelmente oferece também pólen como recurso. A eficiência de frutificação sob condições naturais de polinização (47\%) foi semelhante às encontras para outras espécies de Cactaceae. Pólen de C. laniflorus foi detectado nos morcegos Anoura geoffroy, Glossophaga soricina e Pygoderma bilabiatum. Entre os caracteres relacionados à quiropterofilia encontrados em C. laniflorus, destacamos a coloração creme da parte interna da flor, os estames numerosos e a antese noturna de curta duração. As flores de C. laniflorus também podem ser visitadas por besouros Nitidulidae, abelhas Trigona fulviventris e beija-flores. No entanto, os morcegos são os principais polinizadores desta espécie. Finalmente, por ser uma espécie auto-estéril, C. laniflorus precisa de um polinizador e está mais suscetível ao risco de extinção se qualquer distúrbio afetar de forma negativa o seu sistema de polinização.
\end{abstract}

Palavras-chave: quiropterofilia, espécie endêmica, espécie rara, Serra do Caraça

\begin{abstract}
(Reproductive biology of a highly endemic species: Cipocereus laniflorus N.P. Taylor \& Zappi (Cactaceae)). Cipocereus laniflorus N.P. Taylor \& Zappi is an endemic species from the Serra do Caraça, State of Minas Gerais, Brazil. In order to propose conservation strategies for this species, its reproductive strategies were investigated, including reproductive phenology, floral biology, floral visitors and breeding system. The flowering and fruiting period extends from May to October. Few flowers per plant open each night, producing up to $0.4 \mathrm{ml}$ nectar, but $30 \%$ of them are nectarless. Probably pollen is also offered as a resource. Fruiting efficiency of C. laniflorus (47\%) is close to that found in other Cactaceae species. Pollen of this species was detected in Anoura geoffroy, Soricina glossophaga and Pygoderma bilabiatum bats. Amongst the characteristics related to bat-pollination syndrome found in C. laniflorus, the cream-white colouring of the internal part of the flower, the numerous stamens and the nocturnal anthesis of short duration can be highlighted. Flowers of C. laniflorus are also visited by Nitidulidae beetles, Trigona fulviventris bees and hummingbirds, however bats are the main pollinators of this species. Finally, as a self-sterile species, C. laniflorus needs a pollinator and is more susceptible to the risk of extinction if local disturbances affect its pollination system.
\end{abstract}

Key words: bat-pollination, endemic species, rare species, Serra do Caraça

1 Universidade Federal de São Carlos, Departamento de Ecologia e Biologia Evolutiva, São Carlos, SP, Brasil

2 Universidade Federal de Goiás, Departamento de Biologia Geral, Goiânia, GO, Brazil

Royal Botanic Gardens, Kew, UK / Gardens by the Bay, Singapore, Singapore

4 Author for correspondence: edivanif@gmail.com 


\section{Introduction}

Cactaceae comprises ca. 124 genera and around 1500 species distributed almost exclusively within the American Continent, with major centres of diversity in the arid regions of Mexico, central Andes (Argentina and Bolívia) and Eastern Brazil (Barthlott \& Hunt 1993; Hunt et al. 2006; Taylor \& Zappi 2004). Floral characters, such as colour, size, position of reproductive structures and time of anthesis are very diverse, and the species present a large array of pollination syndromes (see Faegri \& Van der Pijl 1979) and several groups of invertebrates and vertebrates have been observed as visitors and pollinators, such as bees (Grant \& Grant 1979; Mandujano et al.; 1996), beetles (Grant \& Connell 1979), hawkmoths (Silva \& Sazima 1995; Locatelli \& Machado 1999a), birds and bats (Alcorn et al. 1961, McGregor et al. 1962; Locatelli \& Machado 1999b; Aona et al. 2006; Rocha et al. 2007).

Amongst the cacti occurring in the Cadeia do Espinhaço (Minas Gerais, Brazil), Zappi (1989) suggested that species of Uebelmannia, Hatiora and Opuntia might be pollinated by bees, while species of Cereus, Discocactus and Arthrocereus might be pollinated by hawkmoths, Pilosocereus and Cipocereus are probably pollinated by bats, while Melocactus and Arrojadoa might be pollinated by hummingbirds, based on their floral morphology. Several studies of columnar cacti pollinated by bats have been published (McGregor et al. 1962; Fleming et al. 1994; Petit 1995; Valiente-Banuet et al. 1996; Rocha et al. 2007), and it is possible that this pollination syndrome will prove to be frequent, if not the most common one, within tribes Pachycereeae and Cereeae. Recent studies have increased the list of bat-pollinated cacti in the Neotropics, such as Pachycereus pringlei (Fleming et al. 1994), Neobuxbaumia mezcalaensis, Neobuxbaumia macrocephala (Valiente-Banuet et al. 1997), Stenocereus griseus, Pilosocereus moritzianus, Pilosocereus lanuginosus, Cereus [Subpilocereus] horrispinus (Nassar et al. 1997), Pilosocereus catingicola (Locatelli et al. 1997), and Pilosocereus tuberculatus (Rocha et al. 2007).

Cross-pollination has been detected in Cactaceae. Amongst 55 taxa studied by Ross (1981), seeds are produced mainly through self-pollination in only 11 taxa, while 44 taxa produce seeds by cross-pollination. Tacinga [Opuntia] palmadora and Melocactus zehntneri are self-compatible (Locatelli \& Machado 1999a). Pilosocereus catingicola is a self-incompatible species that depends on the presence of bats for its pollination (Locatelli et al. 1997). Pilosocerus moritzianus is partially self-compatible, but its flower has hercogamy (Nassar et al. 1997). Some columnar cacti are self-compatible, however the number of seeds produced by self-pollination is significantly lower than that produced by cross-pollination (McGregor et al. 1962; Fleming et al. 1994).

The genus Cipocereus comprises six species endemic to rock outcrops of the State of Minas Gerais. No study on the reproductive biology of this genus has been reported.
Cipocereus laniflorus N.P. Taylor \& Zappi is endemic to the Serra do Caraça and with the complete population found within the private protected area known as "Reserva Particular de Patrimônio Natural (RPPN) do Caraça”. C. laniflorus has been assessed as endangered because it occurs over a restricted area of distribution and has a small population size (IUCN 2001). In order to propose conservation strategies for this species, we investigate how C. laniflorus is reproducing in this area. This work aims at answering the following questions: Is this species pollinator-dependent for reproduction and what are its pollinators? What are the particulars of its breeding system?

\section{Material and methods}

\section{Study area}

The present study was carried out within the "Reserva Particular de Patrimônio Natural (RPPN) do Caraça” (20 $06^{\prime} \mathrm{N}, 43^{\circ} 27^{\prime} \mathrm{W}$ ), located within the municipalities of Santa Bárbara and Catas Altas, State of Minas Gerais, Brazil. This RPPN has 11,233 hectares, being 10,180 hectares protected, while 1,053 hectares are intended for sustainable management. This area is placed at the southern end of the Cadeia do Espinhaço. The landscape is composed of alternating plateaux amongst quartzitic rocks forming peaks and sculpted crests, at altitudes varying between 750 and 2070 metres. Cipocereus laniflorus occurs in the quartzitic open grasslands within altitudes varying between 1020 and 1815 metres. The main vegetation formation within the study area is known as 'campo rupestre' (rock outcrops) (Harley 1995, Giulietti et al. 1987, Pirani et al. 2003), forming a mosaic with cloud forests and a smaller influence of 'cerrado' vegetation. The reserve is surrounded mostly by pasture, degraded vegetation and iron-ore mines, while fragments of primary and secondary vegetation are rare. According to Köppen's climatic classification Caraça climate is Cwb, mesothermic, rainy, temperate, with mean temperature of the warmest month not over $22^{\circ} \mathrm{C}$ (Antunes 1986). The present study was carried out between August 2001 and October 2003.

\section{Study species}

Cipocereus laniflorus is a moderately woody, shrubby cactus branching at ground level and above the ground, with green to grey-green, 5-ribbed branches. The oval, spine-and-hair bearing areoles are contiguous, becoming almost indistinguishable from each other (Fig. 1A). Flowers are hermaphrodite and borne on lateral to subterminal, bristly to long-spined areoles of the branches. The flower-buds are cylindric, acute at apex. Open flowers reach 60-70 $\mathrm{mm}$ long and 30-40 mm diam., anthesis is nocturnal, pericarpel and tubes are bluish and ribbed externally, bearing sparse scales protecting areoles with white hairs and thin spines. The perianth-segments have fimbriate margins, the outer ones are purplish-cream while 
the inner ones are white. Stamens are very numerous, filaments stout and anthers all located at the same level, slightly below the eight-lobed stigma (Fig. 1B). Fruits are 30-40 mm long and 20-30 mm diam., indehiscent, ovoid when ripe, with persistent perianth remains blackened and dried (Fig. 1C). The pericarpel is bluish with areoles with white tricomes and thin spines. The funicular pulp is translucent, and seeds are black (Fig. 1D).

In order to check the abundance and distribution of C. laniflorus plants, the main trails inside the RPPN do Caraça were surveyed. Every plant of C. laniflorus found was counted. Twelve patches of this species located mainly in quartzitic grasslands were found. These patches were from 0.6 to $8 \mathrm{~km}$ apart and were considered as different sub-populations of 6 to 81 adult plants. The present study was carried out in three of the largest patches.

\section{Reproductive Phenology}

Flowering and fruiting of all young and adult specimens in two subpopulations (one with 37 specimens and another with 113 specimens) were recorded. The number of flowerbuds, flowers and fruits formed per branch in each specimen was recorded monthly throughout 2002.

\section{Floral biology}

Observations of colouring and scent of flowers, as well as anthesis time, position of anthers and stigma-lobes, volume and concentration of nectar were used to infer the pollination syndrome. Anther opening and stigma receptivity were observed in 30 flowers of 30 specimens. Nectar volume and concentration of 30 flowers was measured at different times from anthesis to flower closing, with a graduated $1 \mathrm{ml}$ syringe. Concentration of solutes was measured in 30 flowers using a pocket refractometer "Atago" model "Ni" (0-80\%). Pollen-grain viability was estimated by an indirect method of colouring with acetic carmine (Dafni 1992), wherein only coloured grains are considered viable. Separate slides with fresh pollen from five specimens were prepared and 100 pollen grains per sample were counted under a light-microscope.

\section{Floral visitors}

Floral visitors and their behaviour were registered both as an exclusive activity and while performing other experiments. Diurnal visitors were observed for approx. 60 hours and photographed. Insects were captured with nets and sent to specialists for determination. The captured samples were deposited in the entomological collections of the Zoology Departments of the Universidade Federal de Minas Gerais and Universidade Federal do Paraná. Nocturnal visitors were observed for approx. 30 hours, plus 30 hours of filming focused on open flowers, while three mist nets measuring $2 \mathrm{x}$ $6 \mathrm{~m}$ and $3 \times 12 \mathrm{~m}$ were fixed during 6 nights. The nets were stretched at 18:00h and collected in the morning at around 7:00h, and were examined every 30 minutes.

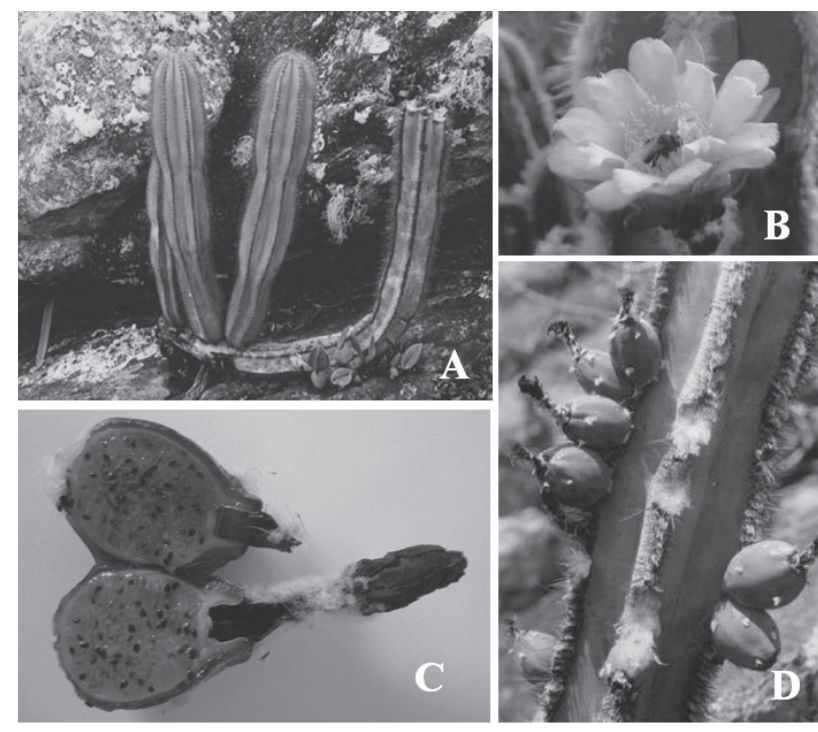

Figure 1. Characteristics of Cipocereus laniflorus N.P. Taylor \& Zappi: A) plant habit; B) open flower visited by a Trigona fulviventris; C) branches with fruits; D) fruits and seeds.

Samples of pollen load on the visitor's body were removed with glycerine jelly treated with fuchsine (Beattie 1971). The samples were mounted on slides for determination under a light microscope. These samples were compared with pollen grains directly obtained from specimens of $C$. laniflorus and others species that were flowering in the study area, bearing in mind that $C$. laniflorus is the only cereoid cactus growing within the reserve and its proximities, and that its pollen is very distinctive.

\section{Breeding System}

In order to determine whether there was an incompatibility system, the following treatments were carried out:

1) Spontaneous self-pollination ( $n=29$ flowers in 29 specimens): flower-buds were bagged and monitored until flowers aborted or formed fruits.

2) Manipulated self-pollination ( $n=22$ flowers in 22 specimens): flower-buds were bagged until anthesis, when each flower was self-pollinated with its own pollen and bagged again.

3) Cross-pollination ( $\mathrm{n}=15$ flowers in 15 specimens): flower-buds were bagged until anthesis, when each flower was pollinated with fresh pollen obtained from another plant and bagged again.

4) Open pollination, not manipulated ( $\mathrm{n}=17$ flower in 17 specimens): flowers were simply marked and left until the abortion or production of fruits.

Both bagged and marked flowers were periodically inspected until fruits were either aborted or produced. Evaluation of results was based on presence or absence of fruit formation. Treatments 1,2 and 3 used nylon mesh bags. The restricted number of tests, especially for treatment 3 , was due to the small number of flowers available each night. One flower submitted to manipulated self-pollination was 
fixed in FAA 24 hours after pollination, while a spontaneous self-pollination flower was fixed in FAA after 48 hours. The growth of the pollen-tube was observed under fluorescent light microscope using the technique of Martin (1959). Some flowers submitted to spontaneous self-pollination $(\mathrm{n}=10)$, manipulated self-pollination $(\mathrm{n}=8)$ and crosspollination $(n=2)$, but that did not form fruits, were also fixed in FAA after falling off, to verify germination and growth of pollen-tube.

\section{Results}

\section{Reproductive phenology}

The flowering and fruiting period occurs between May and October (Fig. 2). The flowering peak was registered in May and July. According to the types proposed by Newstrom et al. (1994), the flowering pattern of $C$. laniflorus can be classified as of long duration. Flower development is not simultaneous and different stages, such as buds, open flowers and fruits can be simultaneously found in the same plant. The flowers stay open for one night only and, when fertilized, fruit formation takes around 40 to 50 days.

Specimens have 1 to 13 branches, and the branches may measure up to $240 \mathrm{~cm}$. Reproductive structures are produced by different size branches and are formed in branches from $20 \mathrm{~cm}$ long. Flowering probability does not increase directly with the length of the branch and medium sized branches produce larger average of buds and flowers. On average, branches between 61 and $80 \mathrm{~cm}$ long had a larger number of reproductive structures (Fig. 3).

\section{Floral biology}

Flower colour when open is cream-white and there was no perceptible scent. Anthesis only lasts one night, beginning at dusk (around 17:00h), closing in the morning (around 9:00h). The anthers open at the beginning of anthesis and the stigma becomes receptive, with lobes spreading, at around 23:00h, staying receptive until 7:00 to 7:30h. The multi-lobed stigma (8-lobed) is found centrally in the flower, at the same height as the anthers. Approximately 93\% of the pollen grains were coloured by acetic carmine and are apparently viable.

Nectar production starts around 22:00h and continues throughout the anthesis period. In the absence of consumption by floral visitors, no evidence was found that nectar was reabsorbed. Nectar volume ( $\mathrm{n}=30$ flowers) varies from flower to flower and specimen to specimen, and the maximum found was $0.4 \mathrm{ml}$ per flower. On average, flowers of C. laniflorus produce $0.192 \mathrm{ml}( \pm 0.127 \mathrm{ml})$ of nectar. Thirty percent of the monitored flowers did not produce nectar. The concentration of solubles ( $\mathrm{n}=20$ flowers) was $17.95 \pm$ $3.25 \%(11-22 \%)$.

\section{Floral visitors}

The following day-time visitors were found: beetles (Family Nitidulidae), bees (Trigona fulviventris) and unidentified hummingbirds. The beetle pierces through the flower-bud and remains inside the flower until after it closes. It walks over the anthers during the visit, collecting large amount of pollen, but it was not seen touching the stigma surface. The bee Trigona fulviventris is present in the flowers less often than the beetle, seeking nectar and consequently carrying pollen, however it rarely touches the stigma. Hummingbirds were observed flying near the flowers at late afternoon and at dawn, however only one individual was seen collecting nectar at 17:00h and touching the anthers and stigma. Ants also visited the flowers, harvesting pieces of perianth segments.

Night-time observations recorded visits by the Nitidulidae beetles only. Hawk-moths hover over the flowers but were not seen visiting them. Night-time filming recorded twice the presence of bats near open flowers of $C$. laniflorus. Hawk-moths, ants and small spiders were also recorded in the films, but they were not seen visiting the flowers. Eleven bats, belonging to 5 species, were captured in 6 nights (Tab. 1). Pollen of C. laniflorus was found on two Glossophagineae: Anoura geoffroy, Glossophaga soricina and one Stenodermatinae, Pygoderma bilabiatum. These three species also had pollen of one to four other species. The Stenodermatinae bats Artibius lituratus and Sturnira lilium did not bear pollen of C. laniflorus, however they were bearing other types of pollen.

\section{Breeding system}

Tests to verify the incompatibility system have shown that the species studied is self-sterile. Both not manipulated self-pollinated and manipulated self-pollinated flowers failed to form fruits. From fifteen tests of cross-pollination, thirteen flowers formed fruit (88.7\%). Control, or openpollinated flowers formed fruits (8 out of 17), showing fruiting efficiency of $47 \%$ under natural pollination conditions.

In self-pollinated flowers, pollen germination and pollen-tube growth were relatively fast, and several pollen tubes were growing within the style in 24 hours. The arrival of the pollen-tubes to the ovules was not observed, neither their break-up and/or formation of callose deposits, as it was seen in a self-incompatibility reaction. Certainly, there is no sporophytic incompatibility system in C. laniflorus. However, the number of flowers observed was small and more tests are needed to determine the type of self-incompatibility reaction in this species.

Flowers submitted to manipulated self-pollination, spontaneous self-pollination and cross pollination that did not form fruit fell around 15 days after anthesis. After this elapsed period of time, it was no longer possible to evaluate pollen-tube growth and ovary development. However, it was still possible to observe that the styles in these flowers had fluorescent vessels, and that the numerous ovules, still 


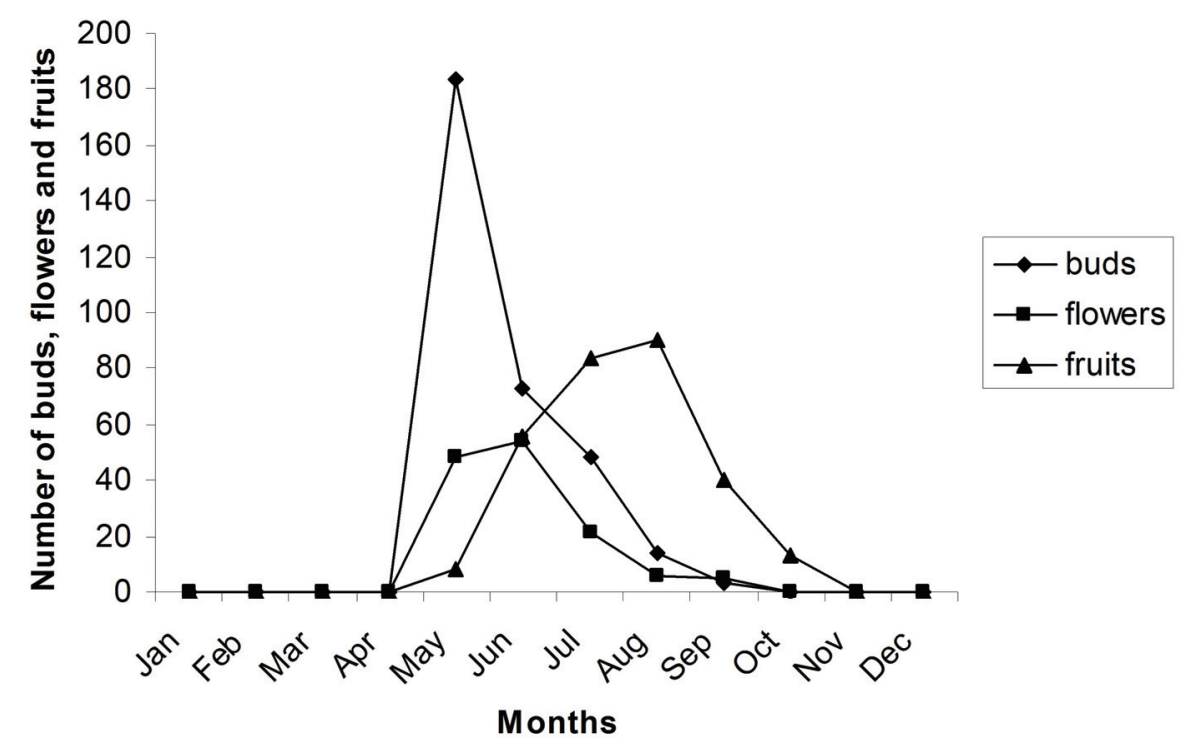

Figure 2. Reproductive phenology of Cipocereus laniflorus N.P. Taylor \& Zappi under natural conditions showing flower-bud, flower and fruit productions.

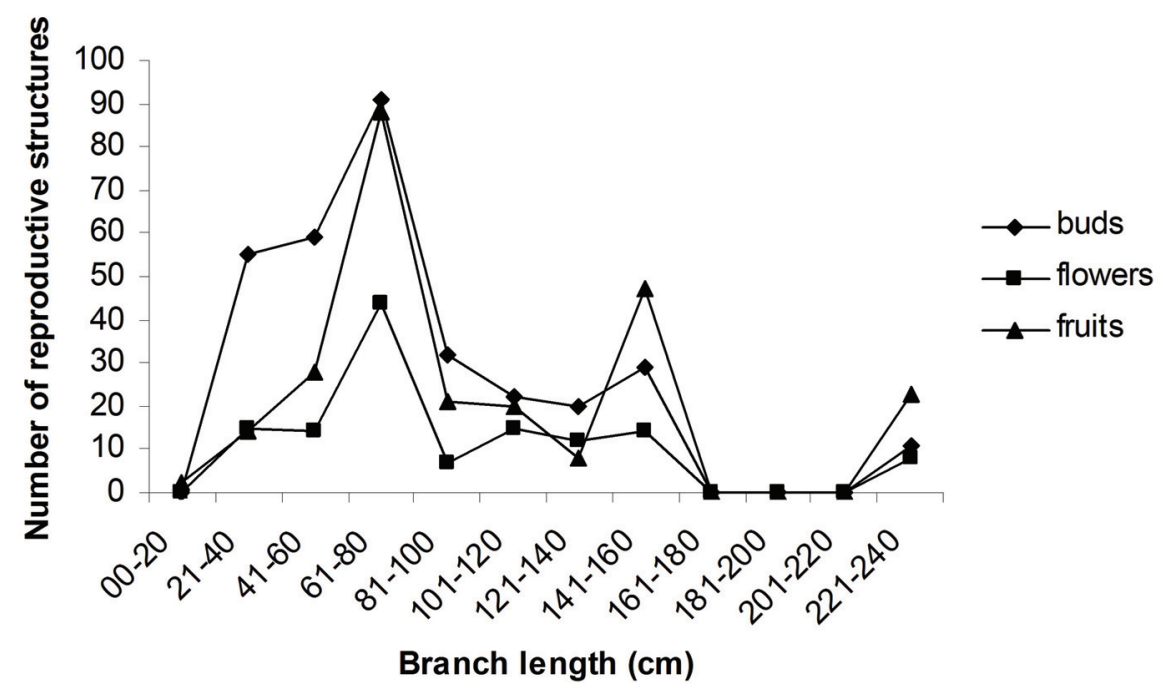

Figure 3. Production of flower-buds, flowers and fruits of Cipocereus laniflorus N.P. Taylor \& Zappi in different of length of branches during the peak of the flowering period.

linked to the placenta through long funicules, had their cell-walls broken.

\section{Discussion}

The flowering season of $C$. laniflorus takes place during the dry, cold months of the year. According to PimientaBarrios \& del Castillo (2002), flowering season in certain cacti is not strongly influenced by water availability, probably due to stem succulence that may supply the plant with enough water to form reproductive structures during the dry season. Therefore, C. laniflorus produces resources such as nectar, pollen and fruits that may feed several species of animals during the dry months, when many other plants are not growing or fertile in the Serra do Caraça. Moreover, the asynchronic pattern of flower and fruit production may be advantageous, making resources available over a long period of time.

Time elapsed between anthesis and fruit ripening is relatively short, as seen in other species of columnar cacti (Pimienta-Barrios \& del Castillo 2002). Fertilized flowers of C. laniflorus develop into ripe fruits within 40 to 50 days, and similar results were seen in Pilosocereus lanuginosus, Stenocereus griseus and Cereus [Subpilocereus] repandus (Petit 1995). Fruiting efficiency of C. laniflorus (47\%) is close to that found in Pilosocereus moritzianus (46\%), Cereus 
Table 1. Captured bats and the amount of pollen grains of Cipocereus laniflorus N.P. Taylor \& Zappi and of other plant species carried on their bodies.

\begin{tabular}{lcc}
\hline Bat species captured & $\begin{array}{c}\text { Number of pollen grains of } C . \\
\text { laniflorus }\end{array}$ & Number of pollen grains of other plant species \\
\hline & 0 & 0 \\
Anoura geoffroy & 2 & 23 (Sp.1), 4 (Sp.2), 1 (Sp.3), $2(\mathrm{Sp} .4)$ \\
& 20 & $5(\mathrm{Sp} .1), 9(\mathrm{Sp} .7)$ \\
Artibius lituratus & 7 & 0 \\
Glossophaga soricina & 0 & 0 \\
Pygoderma bilabiatum & 0 & $5(\mathrm{Sp} .1), 12(\mathrm{Sp} .7)$ \\
Sturnira lilium & 0 & $1(\mathrm{Sp} .1), 1(\mathrm{Sp} .2), 13(\mathrm{Sp} .5), 12(\mathrm{Sp} .6)$ \\
\hline
\end{tabular}

[Subpilocereus] repandus (49\%) and Cereus [Subpilocereus] horrispinus (50\%) (Nassar et al. 1997) and is smaller than for Stenocereus griseus (76\%) (Nassar et al. 1997). Thus, this species seems to have a normal rate of fruiting efficiency, although about $89 \%$ of the control cross-pollinated of its flowers produced fruits, which indicates the occurrence of pollen limitation. Cipocereus laniflorus occurs generally in small patches of 6 to 81 specimens in fertile stage, and a few flowers open each night. Considering that not all the flowers produce nectar, it is probable that the reduced quantity and availability of resources within the area may conduce to a low visiting rate and pollination limitation. On the other hand, another floral resource offered by C. laniforus to its pollinators is its pollen. Then, it is important to ascertain whether the fruiting efficiency of $C$. laniflorus is sufficient to maintain the reproductive success and stable population growth of this endemic and endangered cactus species.

Cipocereus laniflorus does not produce fruits and seeds in the absence of pollinators. Its self-sterility indicates that this is a self-incompatible species and cross-pollination is obligatory for the reproductive success of its populations. However, apart from the evidence of self-incompatibility, some adaptations favouring cross-pollination such as dicogamy and hercogamy were detected. The anthers are open and bear pollen during the whole anthesis (17:00-09:00h), but the stigma generally presents lobes open from 23:00 to $7: 30 \mathrm{~h}$. While the stigma-lobes are placed slightly above or at the same height as the anthers, stigma-lobes are located centrally in the flower and they are not in direct contact with the anthers. The absence of fruit formation in spontaneous and manual self-pollination also indicates absence of agamospermy in C. laniflorus. Despite the evidence of self-sterility, interruption in pollen-tube growth within the style and into the ovary of manually self-pollinated flowers was not observed and more tests are needed to confirm the type of self-incompatibility system.

Amongst the morphological characters related to batpollination syndrome (Faegri \& Van der Pijl 1979) found in C. laniflorus, the cream-white colouring of the internal part of the flower, the numerous stamens and the nocturnal anthesis of short duration are highlighted. Other characters, such as flower relatively short and thick, with straight and relatively wide tube, perianth segments short, filaments not versatile and stigma-lobes relatively wide and short also suggest bat-pollination. Concentration of sugar in nectar of C. laniflorus is similar to that found in bat-pollinated Cactaceae (Nassar et al. 1997; Molina-Freaner et al. 2004) and flowers of other bat-pollinated species from other plant families (Sazima et al. 1982; Sazima et al. 1999). However, in Cactaceae the nectar sugar concentration is not very variable and there is significant overlap between flowers pollinated by different agents (Scogin 1985). It was surprising that no scent was perceptible during the present study, as bad and strong odour is often associated with bat-pollination of cacti (Locatelli et al. 1997; Rocha et al. 2007).

Cipocereus laniflorus produces variable volume of nectar per flower, reaching $0.4 \mathrm{ml}$. The total nectar production in some bat-pollinated Cactaceae exceeds $0.4 \mathrm{ml}$ per flower, with values around $0.44 \pm 0.072$ ml.flowers $^{-1}$. night $^{-1}$ (Locatelli $e t$

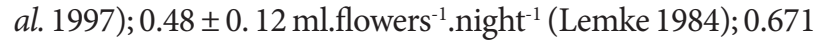
\pm 0.272 a $1.091 \pm 0.452$ ml.flowers $^{-1}$.night ${ }^{-1}$ (Molina-Freaner et al. 2004) and $0.68 \pm 0.46$ ml.flowers $^{-1}$.night ${ }^{-1}$ (ValienteBanuet et al. 1996). Nectar was absent in 30\% of the flowers monitored. Total absence of nectar was also found by Scogin (1985) in flowers of 8 species out of 43 Cactaceae studied. Partial absence of nectar was found by Thakar et al. (2003) in 24 out of 28 studied species, with a percentage of nectarless flowers within different species varying between $1.96 \%$ and $67.82 \%$. It is possible that low volumes and absence of nectar in some flowers of $C$. laniflorus encourages more intense contact between the visitor and the floral parts in search of nectar. Then, contrary to what was discussed above, the occurrence of nectarless flowers may enhance pollen donation and male reproductive success in C. laniforus.

The pollen from Cipocereus laniflorus found on Glossophagineae bats Anoura geoffroy and Glossophaga 
soricina, and on the Stenodermatinae bat Pygoderma bilabiatum was considered to be proof that these bats performed visits to the flowers. Glossophagineae bats are small, light and well adapted to quick visits, able to drink nectar of delicate flowers, while Stenodermatineae are larger and heavier and, according to Heithaus (1982), are better adapted to perform visits where they hang from fruits and strong branches. Glossophagineae bats frequently are associated with 'trapline' routes (Fleming 1982; Lemke 1984), as it has been observed in several studies of bat-pollinated flowers from the Atlantic rain forest (Sazima et al. 1994; Machado et al. 1998; Sazima \& Sazima 1999). This feeding strategy is common in visits to small to medium size plants dispersed within a habitat, where there are few flowers open on each plant and those have long flower-tubes full of abundant nectar (Sazima et al. 1999), leading to a regular revisiting of the individuals dispersed throughout a given area (Lemke 1984; Machado et al. 1998). Stenodermatineae feed changing from one feeding resource to another and may feed in groups, preferring plants with abundant number of open flowers (Sazima \& Sazima 1975; Fleming et al. 1977). The trapline behaviour is favoured by the flowering pattern of $C$. laniflorus, where one to a few flowers opens per night in each plant. Plants of C. laniflorus are found in 12 patches of 6 to 81 fertile individuals in the RPPN do Caraça. Probably, the trapline bats are able to exchange pollen among these patches that may represent subpopulations of a unique metapopulation of these narrowly endemic species, avoiding genetic erosion within it. On the other hand, the mixture of pollen-types carried by the bats captured during this experiment show a promiscuity of visits, that is also characteristic of this feeding type, and can also decrease the pollination efficiency of $C$. laniflorus.

Pygoderma bilabiatum, better known as a frugivore bat, apparently visits $C$. laniflorus flowers without damaging them. It is known that Sternodermatineae bats feed on flowers during the dry season when fruits are hard to come by (Heithaus et al. 1975; Sazima \& Sazima 1975). Slides prepared for deposits found on Artibius lituratus and Sturnira lilium bats did not have signs of pollen from C. laniflorus, but had traces of pollen from other species. Apart from the five species of bat captured, there are records of other bats occurring in the Serra do Caraça, namely the nectarivorous Anoura caudifer and frugivore Carollia perspicillata, Platyrrhinus lineatus and Vampyressa pusilla (Falcão et al. 2003). These are all potential pollinators and fruit dispersers of $C$. laniflorus that can promote long-distance pollen and seed dispersal.

It is possible that hummingbirds may also have an important role in the pollination of this cactus, mainly at dawn, when flowers not visited at night and still with receptive stigma may receive pollen. A generalist pollination system, alternating bird and bat pollination has been studied by Muchala (2003), who found that the small amount of nectar left in the flowers early in the morning did not constitute a barrier for hummingbird visits. Such flexibility may help seed formation in areas where the main pollinator becomes rare. However, only one hummingbird was seen visiting $C$. laniflorus in late afternoon, when the flowers are opening and the stigmas are not receptive yet.

Trigona fulviventris bees make sporadic visits, and their pollen collection in the morning after anthesis is common in many bat-pollinated flowers (Sazima \& Sazima 1975; 1978; Sazima et al. 1982) representing only a type of robbery and being a common behaviour within the group of Meliponinae bees. Small beetles (Family Nitidulidae) perforate C. laniflorus buds and remain in the flower throughout anthesis seeking pollen. These beetles were not seen touching the stigma surface. Because they stay within flowers during anthesis, they may occasionally walk on the stigma. However, it is not very probable that these indeed transfer pollen between sparse specimens with few open flowers per night. They induce mainly self-pollination and do not contribute to increasing the fruiting efficiency. In this case, it appears that the suggestion of Pimienta-Barrios \& del Castillo (2002) of them being pollen/nectar robbers prevails. In Pilosocereus catingicola, small beetles remain in the old flower until two days after the perianth closes (Locatelli et al. 1997).

Vegetative reproduction is very common amongst Cactaceae and is frequently seen in C. laniflorus, through the growth of adventitious roots on fallen branches and also in the form of lengthening of roots through rock crevices, forming new buds and clonal individuals. Asexual reproduction may fix favourable combinations of genes previously produced by sexual reproduction, and also may permit the population growth in the absence of pollinators. However, crossed sexual reproduction is apparently the most important reproductive strategy for $C$. laniflorus because fruit set per plant is high. But, study on population genetic diversity and structure is needed to clarify this assumption.

Finally, as a self-incompatible species, C. laniflorus needs pollinator services and, as an endemic species, it is highly susceptible to the risk of extinction if any disturbance causes negative effect in the local pollinator populations (see Harris \& Johnson 2004). Consequently, the drastic limitation of C. laniflorus fruit production during the dry season may further affect the populations of its pollinators, as well as of its fruit feeders.

\section{Acknowledgements}

We are indebted to the Foundation and Friends of the Royal Botanic Gardens, Kew for the financial support for this work.

\section{References}

Antunes, F.Z. 1986. Caracterização climática do estado de Minas Gerais. Informe Agropecuário 12(138): 09-13.

Alcorn, S.M.; Mcgregor S.E., Olin, G. 1961. Pollination of Saguaro Cactus by Doves, Nectar-feeding Bats, and Honeybees. Science 133(3464): 1594-1595. 
Aona, L.Y.S.; Machado, M.; Pansarin, E.R.; Castro, C.C.; Zappi, D. \& Amaral, M.C.E. 2006. Pollination biology of three Brazilian species of Micranthocereus Backerb. (Cereeae, cactoideae) endemic to the "campos rupestres". Bradleya 24:345-354.

Barthlott, W. \& Hunt, D. R. 1993. Cactaceae. Pp. 161-197. In: Kubitsky, K., Rohwer, J.G., Bittrich, V. (Eds.). The Families and Genera of Vascular Plants. Vol. III, Flowering Plants, Dicotyledons. Berlin, Springer-Verlag.

Beattie, A.J. 1971. A tecnique for the study of insect-borne pollen. Pan Pacific Enthomologist 47: 82.

Dafni, A. 1992. Pollination ecology: a practical approach. New York, Oxford University Press.

Faegri, K \& van der Pijl, L. 1979. Principles of pollination ecology. Oxford, Pergamon Press.

Falcão, F.C., Rebelo, V.F., Talamoni, S.A. 2003. Structure of a bat assemblage (Mammalia, Chiroptera) in Serra do Caraça, South-east Brazil. Revista Brasileira de Zoologia 20(02): 347-350.

Fleming, T.H.; Heithaus, E.R.; Sawyer, W.B. 1977. An experimental analysis of the food location behaviour of frugivorous bats. Ecology 58(3): 619-627.

Fleming, T.H. 1982. Foraging strategies in plant-visiting bats. Pp. 287-325. In: Kunz, T.H. (Ed.) Ecology of bats. New York, Plenum Press.

Fleming, T.H.; Maurice, S.; Buchmann, S. L.; Tuttle, M.D. 1994. Reprodutive biology and relative male and female fitness in a trioecious cactus, Pachycereus pringlei (Cactaceae). American Journal of Botany 81(7): 858-867.

Giulietti, A.M., Menezes, N.L., Pirani, J.R., Meguro, M. \& Wanderley, M.G.L. 1987. Flora da Serra do Cipó, Minas Gerais: caracterização e lista das espécies. Boletim de Botânica da Universidade de São Paulo 9: 1-151.

Grant, V.K \& Grant, K.A. 1979. Pollination of Echinocereus fasciculatus and Ferocactus wislizenii. Plant Systematics and Evolution 132: 85-90.

Grant, V.K. \& Connell, W.A. 1979. The association between Carpophilus beetles and cactus flowers. Plant Systematics and Evolution 133:99-102.

Harley, R.M. 1995. Introdução. Pp. 1-78. In: Stannard, B.L. (Ed.) Flora of the Pico das Almas, Chapada Diamantina, Bahia, Brazil. Kew, Royal Botanic Gardens.

Harris, L.F. \& Johnson S.D. 2004. The consequences of habitat fragmentation for plant-pollinator mutualisms. International Journal of Tropical Insect Science 24: 29-43.

Heithaus, E.R.; Fleming, T.H. \& Opler, P.A. 1975. Foraging patterns and resource utilization in seven species of bats in seasonal tropical forest. Ecology 56: 841-845.

Heithaus, E.R. 1982. Coevolution between bats and plants. Pp. 327-367. In: Kunz, T.H. (Ed.). Ecology of bats. New York, Plenum Press.

Hunt, D.R., Taylor, N.P. \& Charles, G. 2006. The New Cactus Lexicon, 2 vols (Text \& Atlas). Milborne Port, dh books.

Lemke, T.O. 1984. Foraging ecology of the long-nosed bat Glossophaga soricina, with respect to resource availability. Ecology 65: 538-548.

IUCN. 2001. IUCN Red List Categories and Criteria: Version 3.1. IUCN Species Survival Commission. Cambridge, IUCN.

Locatelli, E. \& Machado, I. C. 1999a. Floral biology of Cereusfernambucensis: a sphingophilous cactus of restinga. Bradleya 17: 86-94.

Locatelli, E. \& Machado, I.C. 1999b. Comparitive study of the floral biology in two ornithophilous species of Cactaceae: Melocactus zehntneri and Opuntia palmadora. Bradleya 17: 75-85.

Locatelli, E.; Machado, I.C.S. \& Medeiros, P. 1997. Floral biology and pollination in Pilosocereus catingicola (Cactaceae) in Northeastern Brazil. Bradleya 15: 28-34.

Machado I.C.S.; Sazima I. \& Sazima M. 1998. Bat pollination of the terrestrial herb Irlbachia alata (Gentianaceae) in northeastern Brazil. Plant Systematics and Evolution 209: 231-237.

Mandujano, M.D.C.; Montana, C. \& Eguiarte, L.E. 1996. Reproductive ecology and inbreeding depression in Opuntia rastrera (Cactaceae) in the Chihuahuan desert: Why are sexually derived recruitments so rare? American Journal of Botany 83(1): 63-70.

Martin, FW. 1959. Staining and observing pollen tubes in the style by means of fluorescence. Staining Technology 34(3): 125-128.
Mcgregor, S.C.; Alcorn, S.M.; Kurtz, E.B. \& Olin, G. 1962. Pollination and pollinating agents of the saguaro. Ecology 43: 259-267.

Molina-Freaner, F.; Rojas-Martínez, A.; Fleming, T.H. \& Valiente-Banuet, A. 2004. Pollination biology of the columnar cactus Pachycereus pectenaboriginum in north-western México. Journal of Arid Environments 56: $117-127$.

Muchala, N. 2003. Exploring the boudary between pollination syndromes: bats and hummingbirds as pollinators of Burmeistera cyclostigmata and B. tenuiflora (Campanulaceae). Oecologia 134(3): 373-380.

Nassar, J.M.; Ramírez, N.; Linares, O. 1997. Comparative pollination biology of Venezuelan columnar cacti and the role of nectar-feeding bats in their sexual reproduction. American Journal of Botany 84(7): 918-927.

Newstrom, L.E.; Frankie, G.W.; Baker, H.G. 1994. A new classification for plant phenology based on flowering patterns in lowland tropical rain forest trees at La Selva, Costa Rica. Biotropica 26(2): 141-159.

Petit, S. 1995. The pollinators of two species of columnar cacti in Curaçao, Netherlands Antilles. Biotropica 27(4): 538-541.

Pimienta-Barrios, E.; Del Castillo, R.F. 2002. Reprodutive Biology. Pp.7590. In: Nobel, P.S. (Ed.). Cacti: Biology and Uses. London, University of California

Pirani, J.R.; Mello-Silva, R. \& Giulietti, A.M. 2003. Flora de Grão Mogol, Minas Gerais, Brasil. Boletim de Botânica da Universidade de São Paulo 21(1): 1-24.

Rocha E.A.; Machado I.C. \& Zappi D.C. 2007. Floral biology of Pilosocereus tuberculatus (Werderm.) Byles \& Rowley: a bat pollinated cactus endemic from the "Caatinga" in northeastern Brazil. Bradleya 25: 129-144.

Ross, R. 1981. Chromosome counts, cytology, and reproduction in the Cactaceae. American Journal of Botany 68(4): 463-470.

Sazima, M.; Buzato, S. \& Sazima, I. 1999. Bat-pollinated flower assemblages and bat visitors at two Atlantic Forest Sites in Brasil. Annals of Botany 83(6): 705-712.

Sazima, M.; Fabián, M.E. \& Sazima, I. 1982. Polinização de Luhea speciosa (Tiliaceae) por Glossophaga soricina (Chiroptera, Phyllostomidae). Revista Brasileira de Biologia 42(3): 505-513.

Sazima, M.; Sazima, I.; Buzato, S. 1994. Nectar by day and night: Siphocampylus sulfurous (Lobeliaceae) pollinated by hummingbirds and bats. Plant Systematics and Evolution 191: 237-246.

Sazima, I.; Buzato, S. \& Sazima, M. 1996. An assemblage of hummingbirdpollinated flowers in a montane forest in southeastern Brazil. Botanica Acta 109: 146-160.

Sazima, M. \& Sazima, I. 1975. Quiropterofilia em Lafoensia pacari St. Hil. (Lithraceae), na Serra do Cipó, Minas Gerais. Ciência e Cultura 27(4): 405-416.

Sazima, M. \& Sazima, I. 1978. Bat pollination of the passion flower, Passiflora mucronata, in southeastern Brazil. Biotropica 10(2): 100-109.

Scogin, R. 1985. Nectar constituents of the Cactaceae. The Southwestern Naturalist 30(1): 77-82.

Silva, W.R. \& Sazima, M. 1995. Hawkmoth pollination in Cereus peruvianus, a columnar cactus from southeastern Brazil. Flora 190(3-4):339-343.

Stiles, F.G. 1975. Ecology, flowering phenology, and hummingbird pollination of some Costa Rican Heliconia species. Ecology 56(2): 285-301.

Taylor, N.P. \& Zappi, D. (2004). Cacti of Eastern Brazil. Kew, Royal Botanic Gardens.

Thakar, J.D.; Kunte, K.; Chauhan, A.K.; Watve A.V. \& Watve, M. G. 2003. Nectarless flowers: ecological correlates and evolutionary stability. Oecologia 136(4): 565-570.

Valiente-Banuet, A.; Arizmendi, M.C.; Rojas-Martínez, A.; DomínguezCanseco, L. 1996. Ecological relatioships between columnar cacti and nectar feeding bat in Mexico. Journal of Tropical Ecology 12(1): 103-119.

Valiente-Banuet, A.; Rojas-Martínez, A.; Arizmendi, M.C.; Dávila, P. 1997. Pollination biology of two columnar cacti (Neobuxbaumia mezcalaensis and Neobuxbaumia macrocephala) in the Tehuacan Valley, Central México. American Journal of Botany 84(4): 452-455.

Zappi, D.C. 1989. A família Cactaceae nos Campos Rupestres da Cadeia do Espinhaço, Minas Gerais, Brasil. Tese de Mestrado, Universidade de São Paulo. 